\title{
The Triangular Fortress of Butrint, Albania New studies for the conservation and the valorisation
} Marco Giorgio Bevilacqua ${ }^{\text {a }}$, Roberto Pierini ${ }^{b}$, Matteo Pierotti ${ }^{c}$, Pietro Ruschid

${ }^{a}$ University of Pisa, Pisa, Italy, ${ }^{a}$ mg.bevilacqua@ing.unipi.it, ${ }^{b}$ r.pierini@ing.unipi.it, ${ }^{\text {c} S t u d i o ~ M a s i e l l o ~ S t r u t t u r e, ~ P i s a, ~}$ Italy, ing.matteopierotti@gmail.com, ${ }^{d}$ University of Pisa, Pisa, Italy, p.ruschi@ing.unipi.it

\begin{abstract}
An important programme of valorisation of the architectural heritage involved the Triangular Fortress in Butrint, in Albania, nowadays UNESCO World Heritage Site.

The little knowledge on this supposedly 15 th-century Venetian fortress represented a stimulating task for a research, which started with the architectural survey of the structure.

Finding information on the time of construction was challenging, the few written books and essays being hardly compatible and lacking confirmation. Therefore, a research was carried out in the State Archives and the Museo Correr Library in Venice, which unveiled unpublished manuscripts and drawings, casting new light on the fortress. On the base of this study, it is now possible to suppose that the Ottomans erected the fortress after 1655. The archive founds, together with the results of the survey analysis, helped also to depict a plausible sequence of the historical phases of construction until its damaging in 1798 .
\end{abstract}

Keywords: Triangular Fortress, conservation, fortification, Ottomans, Venetians.

\section{Introduction}

Butrint (latin Buthrotum) is one of the most important Albanian archaeological sites, located at a short distance from the Greek frontier, opposite Corfu Island, on the western bank of the Vivari Channel. Since 1992, the whole complex of Butrint National Park has been listed among UNESCO World Heritage Sites (fig. 1).

The strategic importance of the site, which acted as a sort of outpost between Corfu and the Balkans hinterland, is manifested by the numerous wars and conquests that Butrint witnessed since the ancient times.

Located on the top of a hill in the Ksamil peninsula, Butrint was inhabited since the middle Bronze Age (Ugolini 1937). The Grecian colonisation during the Archaic period (8th-7th century BC) might be suggested on the basis of the recovery of some ceramics. The traces of a wall dating back to such time, together with the sculpture of the Lion Gate, enable us to conclude that there once was an acropolis with a sanctuary.

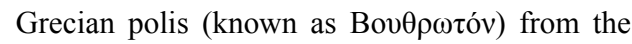
3rd century BC, Butrint became Macedonian Province (Ceka 2006), and the so-called Hellenistic Town and its defensive walls in all likelihood date back to this period (Hodges 2007). The area was included under the Roman Protectorate together with Corfu in 288 BC, and became Colonia Augusta Buthrotum in the 1st century BC. During the Roman Age, the town achieved the ultimate form.

Further developments were registered between the 5th and 6th century AD: new urban walls were erected - although some clues may point to the use of the ancient gates at least until the 
Middle Ages (Sebastiani 2007) - as well as a baptistery and a large Early Christian basilica. Butrint was once again occupied at the end of the 10th century, but the walls were not restored until the period of the so-called Despotate of Epirus at the beginning of the 12th century.

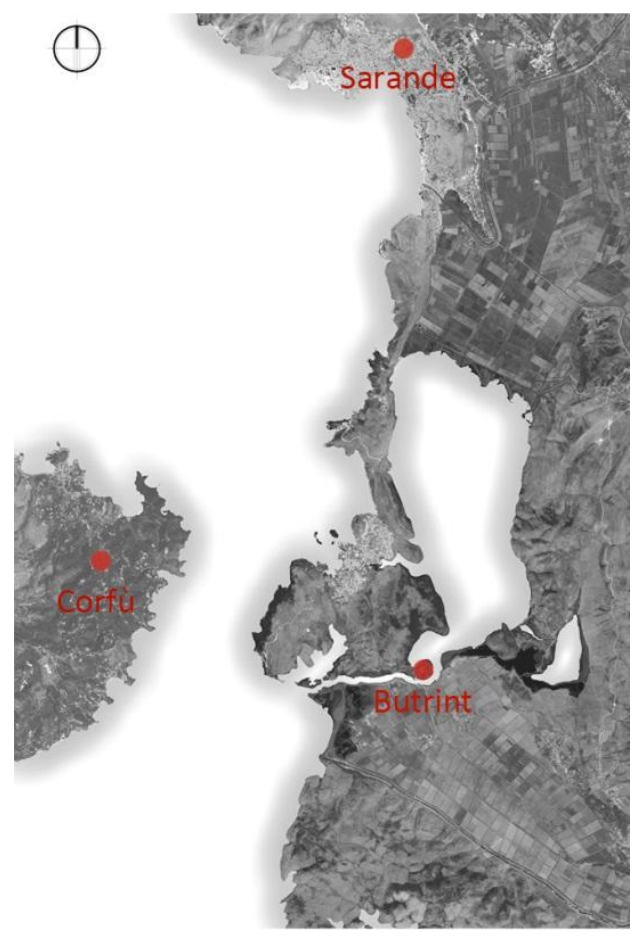

Fig. 1- Butrint geographical location.

After Charles I of Naples's conquest in 1266, different fortunes brought about a series of battles until 1386, when the Republic of Venice decided to conquer the Ionian Islands, including Corfu and, therefore, Butrint. Subjugated by the Ottomans in 1536, Butrint was contended for decades between the two main military powers of the Mediterranean: back under Venetian control after the Battle of Lepanto in 1571, it was besieged by the Turks and abandoned by the Venetians in 1655 , re-conquered by la Serenissima in 1660 and lost again in 1663.

It is during these latter events that it seems possible to place the construction of the Triangular Fortress of Butrint, located on the southern bank of the Vivari Channel and in the middle of a large level ground. Several authors agree on believing that the fortress is part of a complex outpost system that the Venetian Republic erected to control its commercial trades towards the Orient. In fact, Karaiskaj (1984) claims that the construction started between the end of the 14th and the beginning of the 15th century, during the Venetian domination. Crowson (2007) and Hodges (2007), too, attribute the building to the Venetians, but move it to a period between 1490 and the early 16th century. Only recently have a few authors called the Venetian attribution into question, ascribing the building to the Ottomans. Nicolle (2010) believes that the enclosure walls might be a 15th-century Ottoman structure, while Davies (2013) suggests that the building started after 1655.

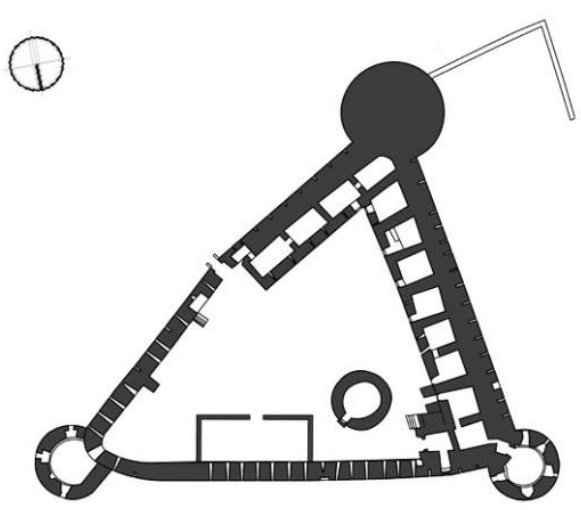

Fig. 2- Ground level plan, original scale 1:50

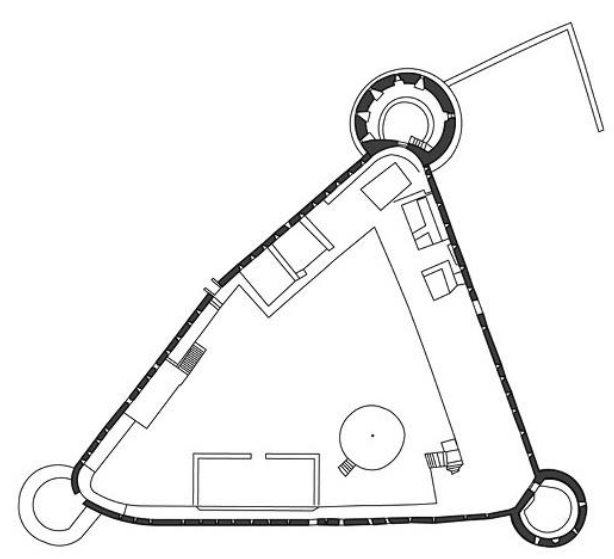

Fig. 3- First level plan, original scale 1:50 


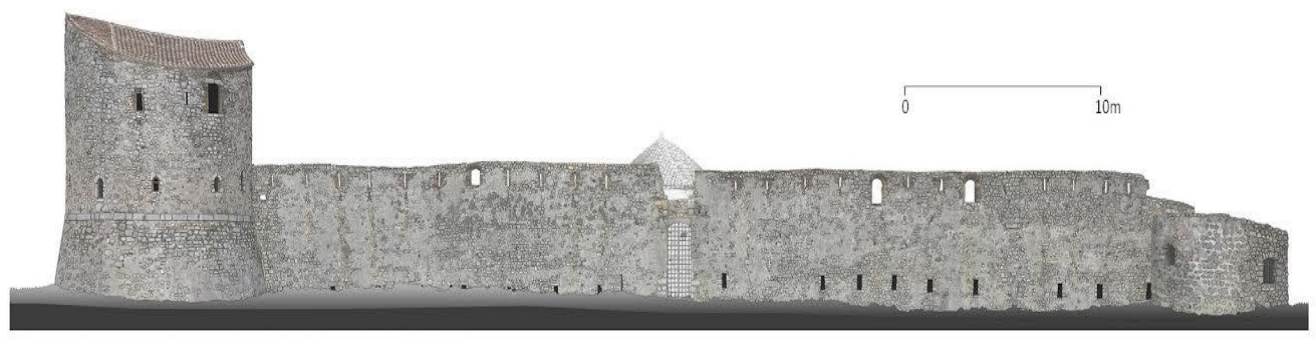

Fig. 4- South-Eastern Front, original scale 1:50

The fortress consists of a triangular enclosure, with circular towers in the corners and a double range of firing loops (figs. 2, 3, 4). The entrance to the fortress is a gateway in the middle of the southeast front of the enclosure. Other gates, now closed, may be noticed on the southwest and north fronts, and might induce us to think of a more complex original connotation of the entrances. Inside the enclosure, there are the remains of some structures, which only in part allow to guess the original organisation of the fortress.

The present article reports the results of a study on the triangular fortress, carried out in 2012 and 2013 as part of a broader research project aimed to the valorisation of Butrint Archaeological Park. The study started off with a thorough architectural survey of the fortress, followed by close stratigraphic analyses and a material and deterioration survey, in order to define the state of conservation of the whole structure and to finally understand the historical phases of the construction.

\section{Historical and critical analysis}

In 1511 the Venetians built a fortified outpost on Butrint acropolis, which was seriously damaged in 1571 during the Ottoman-Venetian wars culminated with the Battle of Lepanto. From that moment on, as Andrea Marmora refers in his 1672 Historia di Corfu, the defences to the access to the Vivari Channel seem to have relied on one tower only, conceivably located on the northern bank of the channell. The construction of a first fortified structure described as royal fortress, and therefore featuring calibres heavier than 8 pounds - is to place in the years after 1655 , when the Ottomans conquered Butrint ${ }^{2}$. What is more, the account reports that when, in 1660, la Serenissima regained control over Butrint after a further attack, the fortress had already been built ${ }^{3}$.

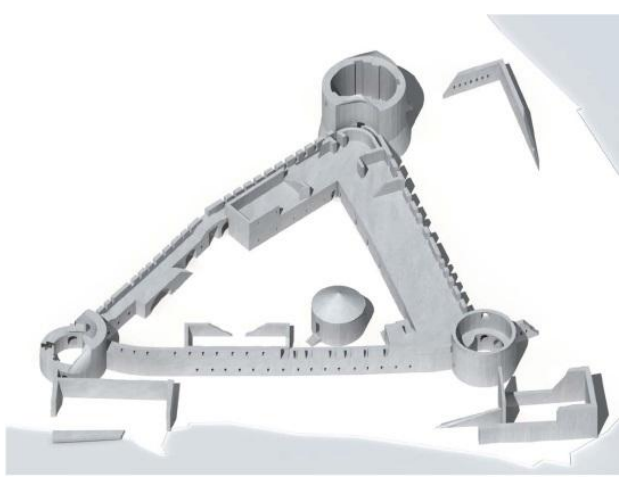

Fig. 5- Triangular Fortress, early $20^{\text {th }}$.

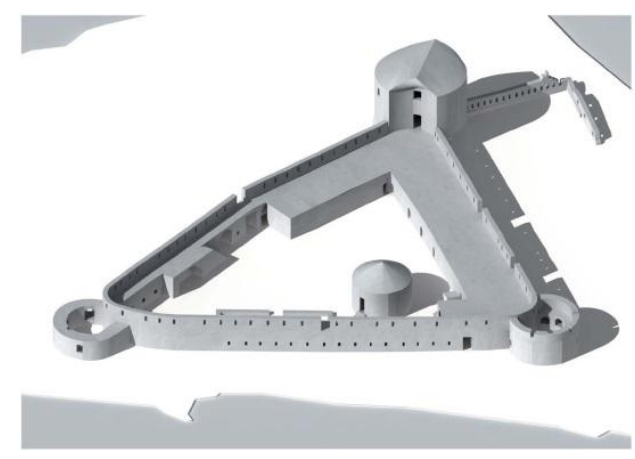

Fig. 6- Triangular Fortress, present.

A first reference to the triangular shape of the fortress appears in a dispatch from a Venetian spy in 1663 , retained in Venice State Archives ${ }^{4}$. In the dispatch, the spy wrote of some fortification works to the walls, which the Turks had started after returning to Butrint in 1655 


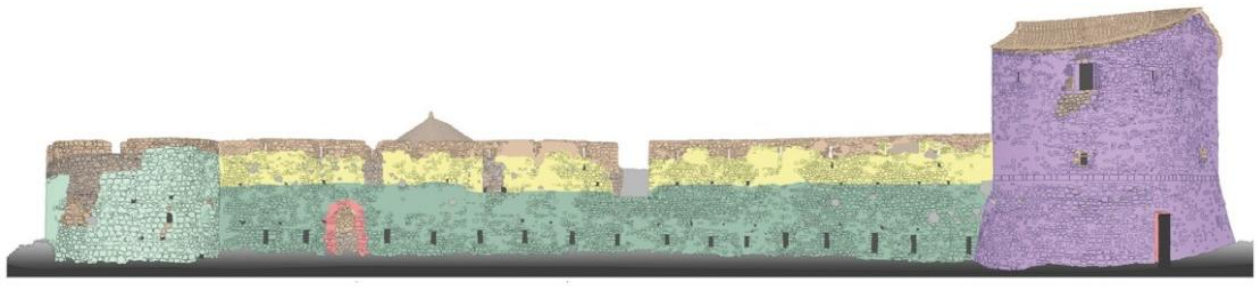

$\begin{array}{llll}1^{\text {st }} \text { phase } & 2^{\text {nd }} \text { phase } & 3^{\text {rd }} \text { phase } \\ \text { circa } 1655 & \text { circa } 1663 & 1684-1716 \\ 4^{\text {th }} \text { phase } & 12^{\text {th }} \text { phase } & 20^{\text {th }} \text {-century } \\ 1684-1716 & 1716-1798 & \text { restorations }\end{array}$

Fig. 7- Western Front: historical phases, original scale 1:100

Moreover, the spy gives a valuation on the height of the fortress wall, considered to be among 1.5 and 2 Venetian feet, approximately 2.60 to 3.40 metres $^{5}$.

There is also the report of another Venetian spy who, in 1684, twenty years after the previous one, provides an accurate description of the fortress, should the Republic decide to conquer it again $^{6}$. The fortress is described as a "large redoubt", with no fortification or defence whatsoever; the report goes on with the description of the enclosure - "a simple wall with no terreplein" - the two gates - "with no palisade or guards; one on the tramontane front almost bathed by the river entering the Lake [...]. The other is towards sirocco on the mainland" - and the river. There is no reference whatsoever to the towers at the corners, whereas all the other nearby towers are carefully described.

The fortress towers, therefore, date back to the late $1600 \mathrm{~s}$. They are depicted in a map from the end of the 17th century (ASVe, Senato, Dispacci Rettori Corfù, foto 30: Disegno M. Forte eretto da' Turchi); their building, sure enough, is subsequent to the triangular enclosure.

An 18th-century map shows a context similar to the present: the fortress features the three circular towers and two rectangular structures inside the enclosure; in addition to this, it is possible to identify a triangular ravelin defending the southern entrance (ASVe, Provveditorato alle Fortezze, 82, disegno 84: Topografia della fortezza di Butrintò). The ravelin, as well as the circular structure inside the enclosure, is also represented in a 1718 Butrint map (MCR, Mappa di Butrinto, anno 1718).

After almost a century, an important description of the fortress is provided by the French (Bellaire 1805, pp. 129-130) ${ }^{7}$, who had come into Butrint in 1797 with the Treaty of Campo Formio; the account of the fortress features adjectives such as "small" and "poorly built". The description of the firing loops is followed by a few important considerations on the layout of the internal structures, such as barracks, a Greek chapel and some storehouses, to satisfy the requirements of a 100-soldier garrison.

The French occupation of Butrint ended on October 25th, 1798: on that very day, the French troops seriously damaged the fortress while retreating ${ }^{8}$. Nevertheless, in 1805 the fortress was still attended by a Vizier and fifteen to twenty soldiers (Leake 1835).

An 1820 incision by lithograph Henry Cook, known as "The Aga's House", shows a Romantic image of the fortress. In the lithography, the southern tower is in its full height but with no roof. On the other hand, the appearance of the northwest tower is completely different from the present: it is depicted as high as the former and with a two-pitch roof; arched loops are located along the upper level. Inside the fortress there are several saddle and hip roofs. The image is completed by some externalstructures, erected on the channel side. 


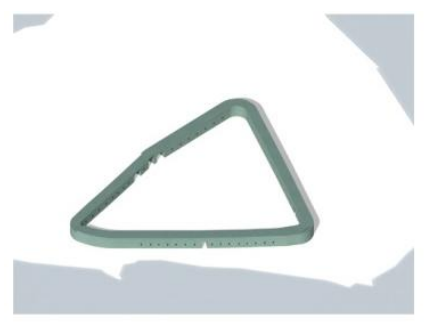

Phase 1 - Circa 1655

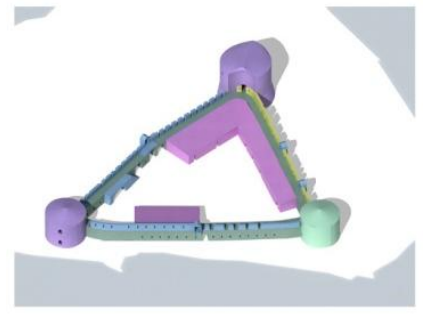

Phase 6 - Circa 1684-1716

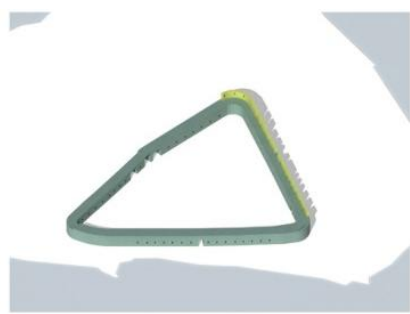

Phase 2 - Circa 1663

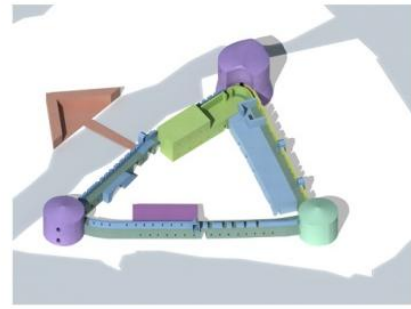

Phase 9 - After 1716

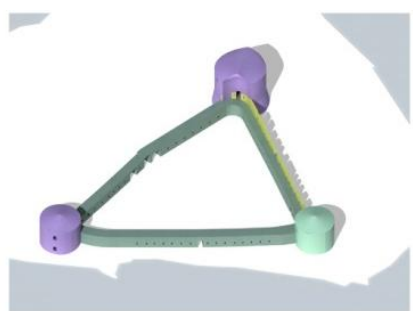

Phase 4 - Circa 1684-1716

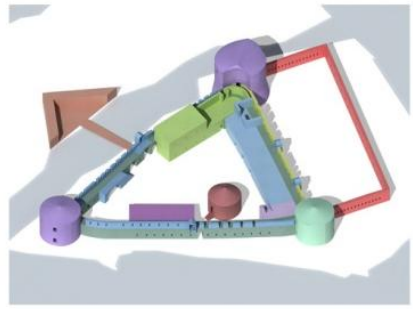

Phase 12 - Circa 1716-1798
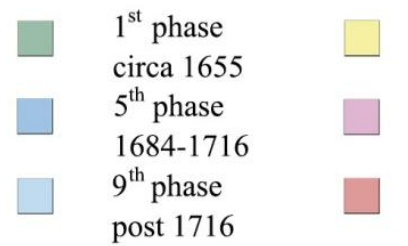

$3^{\text {rd }}$ phase
$1684-1716$
$7^{\text {th }}$ phase
$1684-1716$
$11^{\text {th }}$ phase
$1716-1798$

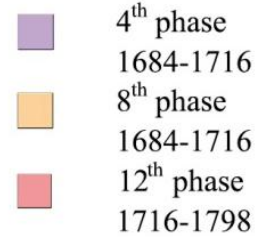

Fig. 8- New ipotheses on the construction phases of the fortress

\section{New hypotheses on the construction phases of the fortress}

The results of the study on bibliographical, archive and iconographic sources - briefly reported in the paragraph above - together with a stratigraphic analysis of the structures, enable us to identify twelve construction phases (figs. 7, 8 ), more or less significant, represented in the schemes of fig. 8, slightly different from those supposed by Karaiskaj in 1974, to which most authors have referred so far.

The first phase consist of the construction, between 1655 and 1660, of the triangular enclosure, featuring firing loops on all fronts and entrances in the middle of the southwest and north fronts, defended by bartizans. Such phase is followed by the erection of a crenelated parapet on the Western front, whose walk was, most probably, reached via wooden ladders. The building of the circular towers in the corners must be placed in the years between 1684 and the end of the century, probably in two different phases. Afterwards, the parapet was built on the two remaining fronts, together with the southern stone staircase, which still permits to get to the parapet walk. The building of the fortress internal structures is more difficult to read. A first stage included the erection of the early south-western structures and the northern room; then, a reorganisation was carried out with the partial demolition of the south-western structures and the building of new rooms attached to the southern side. The southern entrance was fortified with a ravelin between the late 17 th century and 1718 . In that period, the seven vaulted rooms on the western side were erected, too, as well as the round building close 
to the north-western angle. Afterward, the internal structures near the northern entrance and the northwest tower were reconfigured, too.

The erection of an armed outwork on the western site of the fortress constitutes the last identified stage, dating back to the 18th century; the French, then, must have built a wooden drawbridge, which linked the fortress to the "large redoubt" or "stronghold" (maybe the ravelin) across the southwest canal.

\section{Conclusions}

The repeated modifications and changes to which the fortress was subjected during the centuries, together with some recent restorations, have altered the integrity of the masonry, making it difficult to completely understand the history of the building.

If the dating of the identified historical phases still presents an error and integration margin, the research on sources, in particular those from the State Archives in Venice and the Library at the Correr Museum, make it possible to confirm the hypothesis ascribing the building of the fortress to the Ottomans, in the years 1655-1660. The research, not yet concluded, needs further investigations of the documents retained in the Venice Archives. What is more, it is vital to examine in depth a thorough comparison between Butrint triangular fortress and the defensive structures from the Ottoman Area.

\section{Acknowledgements}

The research project, financed with MIUR Cooperlink 2012 funds, is part of a wider project carried out by a group of the University of Pisa, aimed to the valorisation of Butrint Archaeological Park. The research group was composed by: Roberto Pierini (scientific manager), Pietro Ruschi, Marco Giorgio Bevilacqua, Claudia Casini; Francesca Balestri, Francesco N. Botticchio, Federico Ferrazzino, Micol Meucci, Michela Mucciarelli, Matteo Pierotti, Daria Ricci and Mariasimona Silvestri (students of the Master Degree Course of Building Engineering Architecture of the University of Pisa). All the drawings are by the students listed above. Fabio Santaniello,
Alessandro A. Terranova and Claudio Iozzia Maddalieno also collaborated to the architectural survey.

\section{Notes}

(1) "A Butrintò non si fece pensiero di mandar gente, essendo distrutta la Città, e il castello; e bastaua per allora à governare la sicurezza del lago, quella torre, che Cristoforo Condocalli hauea munita con molti braui Corciresi [...]" (Marmora 1672, p. 353).

(2) "[21 maggio 1655] partissi'l Cavaliere [veneziano], e con sommo dolore lasciò la Torre à Turchi, che poi fabbricarono ivi presso una Fortezza Reale [...]" (Marmora 1672, p. 424).

(3) "[I veneziani] per isnidare quelle volpi dalla tana si avvalsero del fumo, accendendo sotto l'arco, che sostiene la torre, molte fascine. Con la medesima felicità fù il giorno seguente presa la Fortezza che fù fabbricata dagli Ottomani" (Marmora 1672, p. 432).

(4) The spy, sent to Butrint, describes "come il Beico avanti il suo partiri havendo datto ordini che fosse incamiciato quel forte Triangolare, che havea fatto alzare l'Inverno passato dalla altra banda della Fiumara all'incontro della nostra Torre dimolita". ASVe, Senato, Dispacci Rettori Corfù, n. 6 .

(5) "[...] può esser alto il muro un passo e mezzo e non credo arrivi a due". ASVe, Senato, Dispacci Rettori Corfù, n. 6.

(6) "[Corfù, 25 maggio 1684] la Fortezza di Botintrò $[\ldots]$ non può dirsi propriamente Fortezza; Bensì un gran Redotto, mentre non ha forma alcuna di fortificatione; questo è di figura triangolare senza difesa immaginabile. Suo recinto è di semplice muro senza alcun terrapieno; di poca altezza e di mediocre grossezza. Il suo giro eccede di poco 150 passa, et il suo aloggio è di due sole case [...]. Vi sono due semplici Porte senza Palizzate né Corpo di guardia; l'una dalla parte di tramontana bagnata quasi dalla fiumara che entra nel Lago [...]. L'altra è verso siroco dalla parte di terra ferma dove solo è facile di prendere quella Fortezza col petardo o con la scaletta; mentre gl'altri due lati da vicino vengono costeggiati dalla fiumara 
suddetta con assai profondità d'acqua". BMC, Ms. Morosini Grimani 527.9.

(7) "Le fort est très-petit, mal construit et distant de la place de Corfou d'environ deux myriamètres. L'artillerie qui defend les courtines est place sur des espèces de panquettes construties en bois, et établies le long de vielles murailles peu épaisses et garnies de créneaux et de fauconneaux; l'artillerie des tours est placée dans des chambres basses et étroites, dont les embrasures et creneaux sont si mal disposes que l'on ne peut obtenir de plongée sur le pied des murailles, ni flanquer les courtines. Le second étage des tours est destine à loger les officiers et une partie de la garnison. Une petite caserne, une chapelle grecque et quelques magasins, sont placés dans l'interieur du fort, et suffisent à peine, avec les chambres supérieures des tours, pour le logement d'une garnison de cent hommes. Tous ces batimens, ainsi que le reste $\mathrm{du}$ fort, sont très-vieux et en assez mauvais état. On a etabli un petit pont - levis la porte place sur la cortine du sud-est. Ce port est couvert, audelà du canal qui borde cette courtine, par un simple redan ou place d'armes. Le fort de Butrinto n'etoit dans le principe qu'une tour batie par Michel III, duc de Corcyre. Les Turcs, ayant pris et détruit cette tour pendant la guerre de Gandie, la rebatirent sur un plan plus etendu. Le maréchal comte de Schulemburgh anleva ce poste en 1716, après le siege de Corfou, et le fit fortifier tel que je viens de le décrire". Bellaire 1805, pp. 129-130.

(8) «Le 4 brumaire il fut décidé, dans un conseil de défense qui se tint chez le général, que le fort de Butrinto seroit évacué, miné, et detrut autant que possible. [...] en moins de douze heures tous les travaux furent exécutés. Lorsque la garnison et tous les effets susceptibles d'etre evacuee eurent été placés dans les barques qui devouieut les conduire à Corfou, l'on mit le feu aux tours $\mathrm{du}$ nord-est et du nord-ouest, et à divers batimens que l'in avoit demolish et étanconnés vers le sol; et l'on fit sauter l'autre tour, don't les fourneaux réussirent parfaitement». Bellaire 1805, p. 271.

\author{
Abbreviations \\ ASVe - Archivio di Stato di Venezia. \\ BMC - Biblioteca del Museo Corrier, Venezia.
}

\section{References}

Bellaire J. (1805). Précis des operations génerales de la Division Française du Levant. MagimelHumbert. Paris.

Ceka N. (2006). Butrinto (in the Italian trans. by E. Bussoni). Migjeni Books. Tirane.

Crowson A. (2007). Butrinti Venecian, Venetian Butrint. Butrint Foundation. Tirane.

Davies S. (2013). "Late Venetian Butrint: 16th-18th centuries", in: Butrint 4: The Archaeology and Histories of an Ionian Town. Hansens I. L., Hodges R., Leppard S. (eds.). Oxbow Books. Oxford.

Hodges R. (2007). "Duecento anni di ricerche a Butrinto. Paradigmi che cambiano", in: Groma 1. Archeologia tra Piceno, Dalmazia ed Epiro. Giorgi E., Vecchietti E., Bogdani J. (eds.). Ante QuemSoc. coop.. Bologna.

Karaiskaj G. (1984). Butrinti dhe fortifikimet e tij (in the English trans. by A. Crowson) Butrint Foundation. London/Tirane. 2009.

Leake W. M. (1835). Travels in Northern Greece. J. Rodwell. London.

Marmora A. (1672). Della historia di Corfu descritta da Andrea Marmora nobile corcirese. Curti. Venezia.

Nicolle D. (2010). Ottoman Fortifications 1300-1710. Osprey Publishing. Oxford.

Sebastiani A. (2007). Leggendo "Roman Butrint" e "Byzantine Butrint". Archeologia Medievale (34).

Ugolini L. M. (1937). Albania Antica 2. Istituto Grafico Tiberino. Roma. 
